\title{
Editorial El ranking iberoamericano de Psicología
}

Recientemente, se dio a conocer el ranking iberoamericano de Psicología, elaborado por Scimago (http://www.scimagoir.com/) bajo un convenio con la Federación Iberoamericana de Asociaciones de Psicología (http://www.fiapsi.org/), a partir de la producción publicada en revistas científicas incluidas en el sistema SCOPUS entre 2005 y 2009. El ranquin incluye universidades y otros organismos que producen investigación en Iberoamérica, y diferencia la calificación latinoamericana de la iberoamericana. Además, considera indicadores tales como cantidad de producción $(\mathrm{O})$, colaboración internacional (IC), calidad científica (IN) y porcentaje de trabajos en primer cuartil (Q1), independientemente de las posiciones por productividad, colaboración o porcentaje de la producción en Q1.

El ranking muestra un panorama que amerita múltiples reflexiones sobre el crecimiento significativo de la producción internacionalmente visible. Por ejemplo, seguramente a dicho crecimiento han contribuido el acelerado ingreso de revistas de Psicología de Iberoamérica a los sistemas de indexación internacional, el papel que han jugado los sistemas de acceso abierto como Psicoredalyc (http://redalyc.uaemex.mx/portales/areas/indices/ psicologia/IndexPsicologia.jsp) en la cualificación de las prácticas editoriales y la puesta en acceso abierto de todo ese conocimiento que se produce en nuestra comunidad lingüística.

Probablemente, también han intervenido las presiones de los sistemas nacionales que piden cuentas sobre la producción como indicador de calidad, las cuales han conducido a un compromiso más claro con el mejoramiento de las condiciones para la investigación (inversión en: formación de doctores, sistemas de contratación de investigadores, infraestructuras de conocimiento, cooperación para la transferencia de conocimiento y recursos para desarrollar proyectos), $\mathrm{y}$, seguramente a todo este complejo panorama, también ha contribuido la institucionalización y el mejoramiento que ha experimentado en especial Latinoamérica en sus procesos de formación (crecimiento en el número de instituciones que trabajan en la formación de psicólogos). En síntesis, este ranking deja ver un panorama vasto y complejo de la Psicología, tanto de Latinoamérica como de Iberoamérica.

La fuerza de la institucionalidad ha permitido superar la época en que nuestras psicologías dependían de uno o dos investigadores. Hoy, tenemos una comunidad productiva que trabaja en múltiples áreas y que no es posible resumir en cortos estados del arte. Hoy, necesitamos sistemas de información que den cuenta de todo este complejo horizonte.

El indicador de cooperación internacional plantea la necesidad de ver qué tanto cooperamos y si estamos construyendo región en esos procesos de cooperación -si consideramos esta cooperación como una oportunidad de construcción conjunta a futuro-. Por otro lado, también genera interrogantes sobre las simetrías internacionales: con quiénes cooperamos para dar visibilidad a nuestro conocimiento y si estamos realmente mejorando nuestras capacidades. 
El indicador de calidad muestra, en especial en Latinoamérica, que aún la visibilidad de nuestros trabajos está en revistas de Q4, principalmente; sin embargo, creo que esto cambiará pronto y que es prematuro analizar tanto en este indicador como en el indicador de porcentaje de trabajos en Q1, por el ingreso reciente de revistas de la región a estos índices y porque nuestras comunidades se encuentran en el proceso de aprender a reconocer y valorar la calidad de la producción de la región.

Wilson López López

Editor 


\section{Editorial The Iberoamerican Psychology Ranking}

A few days ago, the Iberoamerican Ranking of Psychology was presented. This ranking was created by Scimago (http://www.scimagojr.com) through an agreement with the Iberoamerican Federation of Psychology Associations (http://www.fiapsi.org), based on the production published in scientific journals covered by the Scopus system between 2005 and 2009. The ranking includes universities and other research institutions in Iberoamerica, and it separates Latinamerican scores from Iberoamerican scores. It also takes into account indicators such as output $(\mathrm{O})$, international collaboration (IC), scientific quality (IN) and percentage of articles in the first quartile (Q1), independently of the places obtained in productivity, collaboration or Q1 percentage production.

The ranking shows us a situation that demands us to think in various ways about the significant growth of internationally visible output. For example, that growth has been probably influenced by the increased and accelerated coverage of Iberoamerican Psychology journals by the international indexing systems, by the role played by open access systems such as Redalyc (http://redalyc. uaemex.mx/portales/areas/indices/psicologia/IndexPsicologia.jsp) in the quantification of editorial practices, and by the decision of placing the knowledge produced by this linguistic community in Open Access.

It is likely that some other contributions have taken place here as well, for example the pressure exerted by national systems in order to request production statistics as quality indicators. This has led to a clearer commitment to the improvement of research conditions (investment in Doctoral programs and training, researcher contracts, knowledge infrastructure, cooperation for knowledge transfer, and resources for projects). The complex situation has probably been also influenced by the institutionalization and improvement experienced by Latin America in its training processes (a growth in Psychologist training institutions). To summarize, this ranking presents us with a vast and complex view of Psychology in Latin America and Iberoamerica.

The strength of the institutions has managed to overcome the time when our Psychologies depended on the work of one or two researchers. Today, we have a productive community working in different areas, and which cannot be summarized in short state-of-the-art documents. Today, we need information systems that can account for this complex panorama.

The international cooperation indicator requires us to examine how much we cooperate and if we are actually helping the region with these processes of cooperation - if we consider this cooperation as an opportunity to build things together in the future. It also begs some questions regarding international symmetries: who do we cooperate with in order to give visibility to our knowledge, and are we really improving our possibilities?

The quality indicator shows that the visibility of Latin American contributions is still mainly in Q4 journals; however, I believe that this will change soon and that the analysis of this indicator and of 
the Q1 articles indicator is premature, because of the recent coverage of journals by the indexes, and because our communities are learning to recognize and give value to the region's scientific output.

There is no doubt that the growth in research investment, the improvement of the editorial production's quality and the changes in scientific communication practices in the region, will modify these and other indicators. Researchers and editors now have a new source of information for our work that will surely be useful to change our scientific communication practices. A warm welcome to this ranking, and may it contribute to the knowledge of the regional production dynamics and to the discussions emerging from it.

Wilson López López

Editor 